refer the matter to the High Court for sanction, but rather made it a condition of the withdrawal that the stonemason and his firm were required to show cause why they should not be disbarred for a period of twelve months from undertaking works in consecrated ground within the diocese of Chichester. [RA]

doi:10.1017/So956618X1300001X

\title{
Re St Mark, Fairfield
}

Worcester Consistory Court: Fookes Dep Ch, 31 August 2012 Exhumation - mistake - change of law - exceptional circumstances

The deceased moved to Fairfield in 1989 but shortly afterwards became seriously ill and died. He was buried in the churchyard of St Mark, Fairfield, where his son was the incumbent. It was anticipated by all family members that the interment would be temporary and in due course the deceased and his wife would be buried in an established family grave in Great Amwell, where the family had connections dating backover three centuries. The deceased's wife died in 2011 and their son petitioned to exhume his father's body for re-interment at Great Amwell. Unfortunately that son died later in 2011; the petition was pursued by his brother.

The deputy chancellor reviewed the case law and found that, since the interment in 1989, there had been a reformulation of the test for the discretion to grant a faculty to exhume remains. In light of the decision of Re Blagdon Cemetery [2002] Fam 299 the test had changed from one requiring that there be good reason for the exhumation to one requiring special circumstances to justify an exception to the norm of permanence in Christian burial. The task is now one of identifying exceptions and no longer one of merely balancing different considerations. The lack of objections and familial support for the petition were neutral circumstances rather than special circumstances justifying an exception. In this case there had been a mistake caused by changes to the law concerning exhumation between the 1989 burial and the 2011 petition. The petitioner's brother had made a mistake as to the law in assuming at the time of burial that a future request for exhumation for the purposes of re-interment in a family grave was likely to be viewed favourably. The mistake as to law was an exceptional circumstance supporting the petition. The exceptional suddenness of the father's death, the short time between death and interment and the long-standing intention to re-inter in a family grave also amounted to exceptional circumstances justifying a faculty for exhumation. There were credible and good reasons for the lapse of time between burial and petition. The faculty was granted. [Catherine Shelley] 